\title{
DEVELOPMENT AND EVALUATION OF DENSITY AND PORSITY OF
}

\section{ALUMINIUM FOAMS}

\author{
Nikitha D.S ${ }^{1}$, Karthik S.B ${ }^{2}$, Kishore ${ }^{3}$ \\ ${ }^{I} P G$ Scholar, Department of Mechanical Engineering, U.V.C.E, Bangalore, India \\ ${ }^{2}$ Assistant Professor, Department of Mechanical Engineering, Don Bosco Institute of Technology, Bangalore, India \\ ${ }^{2}$ Assistant Professor, Department of Mechanical Engineering, Don Bosco Institute of Technology, Bangalore, India
}

\begin{abstract}
The characteristic of metal foams is a very high porosity typically 75-95\% of the volume consists of void spaces making these ultra light materials. The strength of foamed metal possesses a power law relationship to its density; i.e., a 20\% dense material is more than twice as strong as a 10\% dense material. Methods for producing metal foams are many, but obtaining repeatability in the properties is very difficult. The main challenge posed by the metal foam is that obtaining homogeneous porosity. Metal foams are a new kind of materials with low densities and novel physical, mechanical, thermal, and electrical properties. They can be divided into closed cell and open cell structures Although lot of problems involved in the development of metal foams, research people are attracted to the metal foams because of its attractive properties like acoustic damping, bomb mitigation, light weight etc. By considering the development of Aluminium foams as important aspect, some methods have been adopted and attempts have been made to produce metal foams at lower cost using a different foaming agent which are cheaper than the conventional foaming agent. The methods developed for the Aluminium foams were Aluminium foam production using NaCl crystal as a place holder in the Al melt, Aluminium foam production using NaCl crystal as a place holder in sand salt mould, Aluminium foam production using $\mathrm{NaCl}$ crystal as a place holder by simultaneous pouring i.e., fusion including both foaming agent and salt concept. The problems associated in each process and its effect on the density and porosity of the foam are discussed.
\end{abstract}

Keywords: Al Foams, Density, $\mathrm{NaCl}$, Porosity, Space Holder.

\section{INTRODUCTION}

Cellular materials are wide spread in everyday life and are used for various purposes like cushioning, insulating, damping, constructing, filtering and many more. High porous materials are known to have a high stiffness combined with a very low specific weight. Hence, cellular materials often appear as constructional materials (e.g. Bones and woods) in nature. The fact that even metals and metallic alloys can be produced as cellular solids is not considered as a very good possibility when compared to foams produced using traditional engineering materials such as ceramics, glass and polymers. The defining characteristic of metal foams is a very high porosity typically $75-95 \%$ of the volume consists of void spaces making these ultra light materials. The strength of foamed metal possesses a power law relationship to its density; i.e., a $20 \%$ dense material is more than twice as strong as a $10 \%$ dense material .But metallic foams can be exploited due to the combination of their properties which are related to the metallic character on one end and to the porous structure on the other end. Hence, in the past 40 years many attempts have been carried out in order to foam materials or to produce porous metallic structures .Metal foam is a cellular structure consisting of a solid metal, for example: aluminium, containing a large volume fraction of gas-filled pores. The pores can be sealed (closed-cell foam), or they can form an interconnected network (open-cell foam). The defining characteristic of metal foams is its very high porosity. Typically $75-95 \%$ of the volume consists of void spaces. The strength of foamed metal possesses a power law relationship to its density i.e., a $20 \%$ dense material is more than twice as strong as a $10 \%$ dense material Metallic foams typically retain some physical properties of their base material. Foam made from nonflammable metal will remain non-flammable and the foam is generally recyclable back to its base material. Coefficient of thermal expansion will also remain similar while thermal conductivity will likely be reduced.

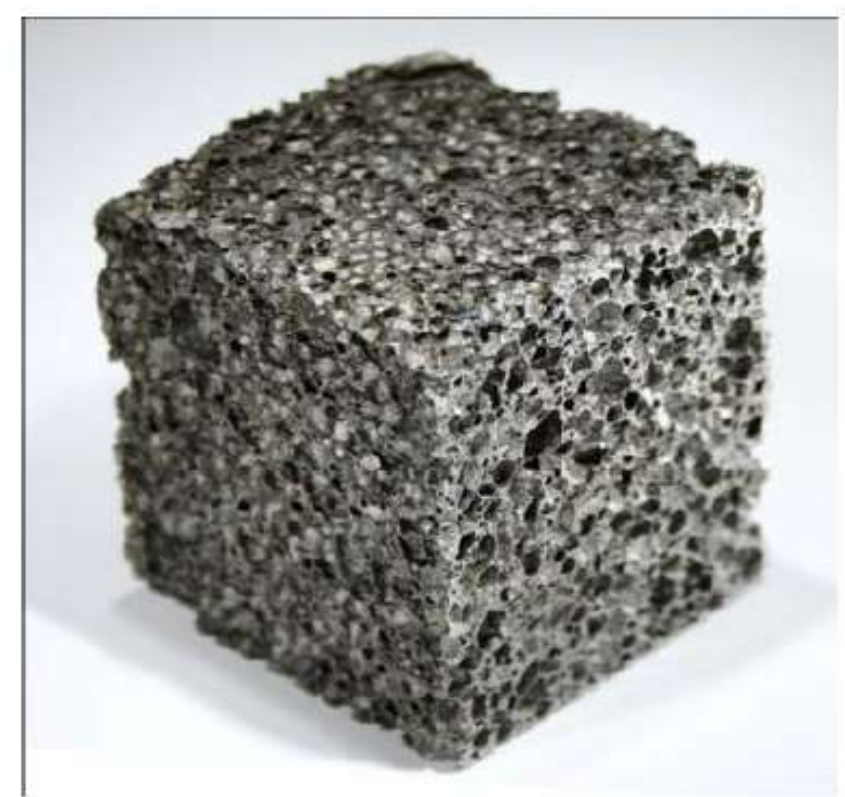

Fig - 1: Aluminium foam 


\section{MATERIALS AND METHODOLOGY}

Our main aim for the project was to prepare metal foam with good porosity and less density compared to actual metal. We synthesized foam in three different methods,

1. Direct Pouring method (Salt Method)

2. Foaming method (using foaming agent)

3. Fusion method

\subsection{Direct Pouring Method (Salt Method)}

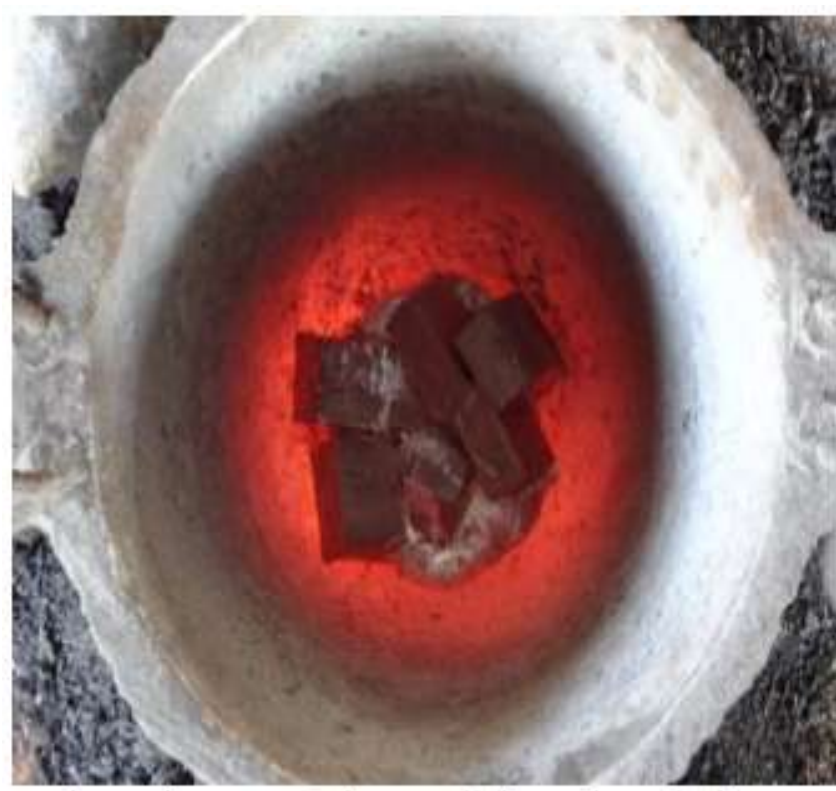

Fig - 2: Showing melting of the aluminium metal in the crucible

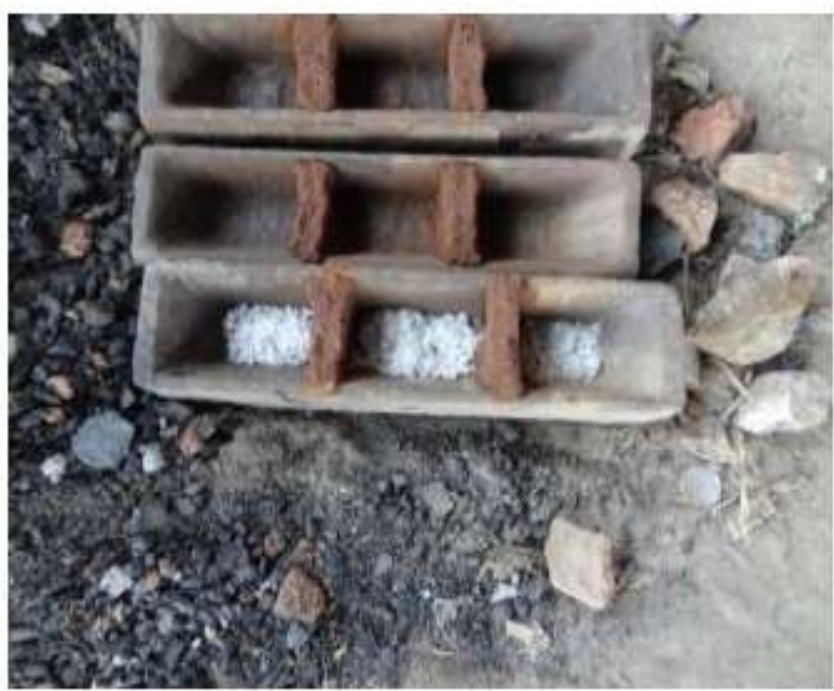

Fig - 3: Showing mould whose bottom is filled with $\mathrm{NaCl}$ crystals.

The foam in this process was synthesized by keeping the density differences of aluminium $(2.7 \mathrm{Kg} / \mathrm{m} 3)$ and Salt $(2.16$ $\mathrm{Kg} / \mathrm{m} 3$ ) in mind. The basic idea was that when molten metal is poured into the mould, due the difference in the density, the salt crystals will try to come up hence creating pores in the casted metal.

\section{Raw Materials:}

1. Aluminium ingot $(1 \mathrm{~kg})$

2. $\mathrm{NaCl}$ Crystals (500 gms)

\section{Procedure:}

1. Aluminium ingot is placed in the crucible for melting.

2. Once the metal is melted, care must be taken so that the temperature of the melt is maintained in the desired range.

3 . The desired temperature range of the melt is between 6600-6900 C.

4. On the other hand, the mould is cleaned.

5. $\mathrm{NaCl}$ crystals are placed at the bottom of the cleaned mould.

6. When the metal is completely melted, it is poured into the mould containing $\mathrm{NaCl}$ crystals.

7. The metal is allowed to cool for sometime (about half an hour).

8. After the solidification, the casting is removed from the mould and is taken for the leaching process.

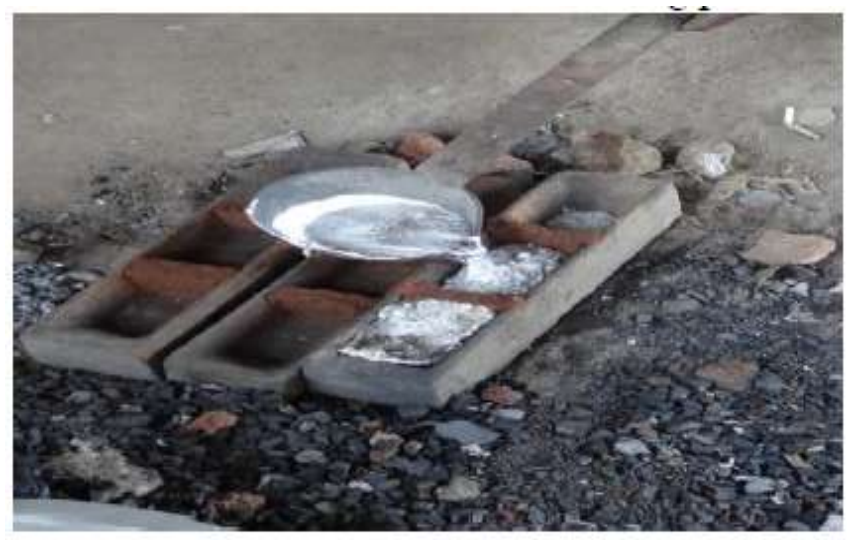

Fig - 4: Molten metal poured into the mould having $\mathrm{NaCl}$ crystals

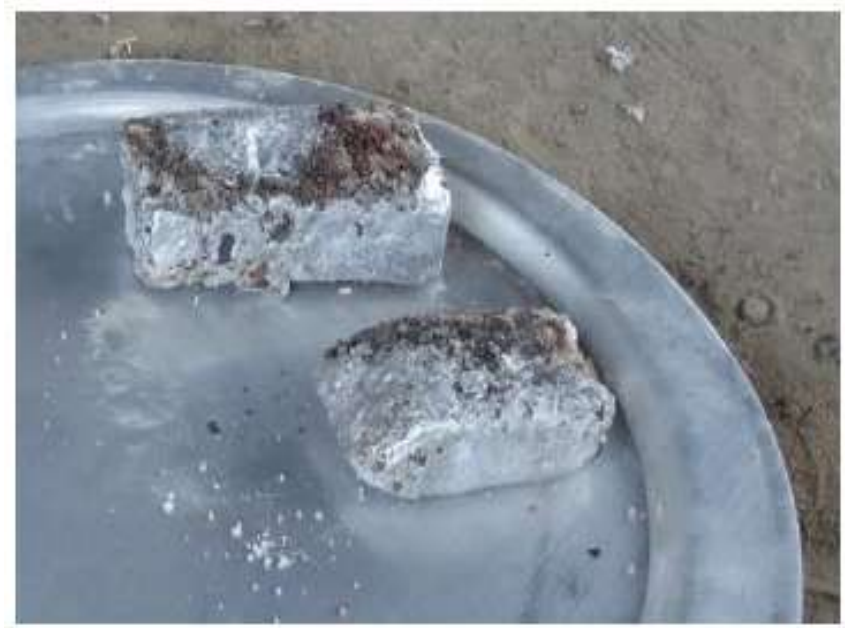

Fig - 5: - Cast metal removed from the mould 


\subsection{Foaming Method}

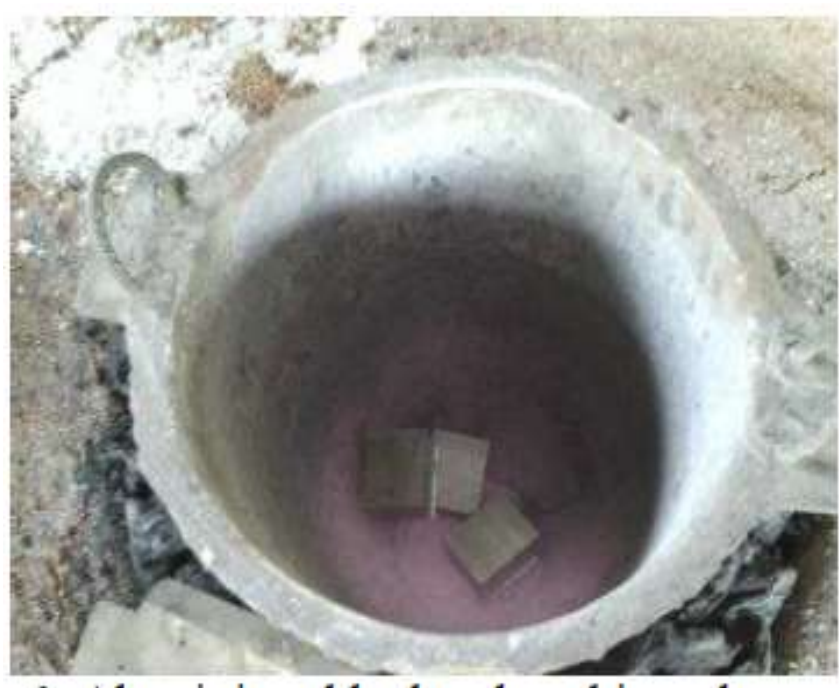

Fig - 6: Aluminium blocks placed into the crucible for melting process

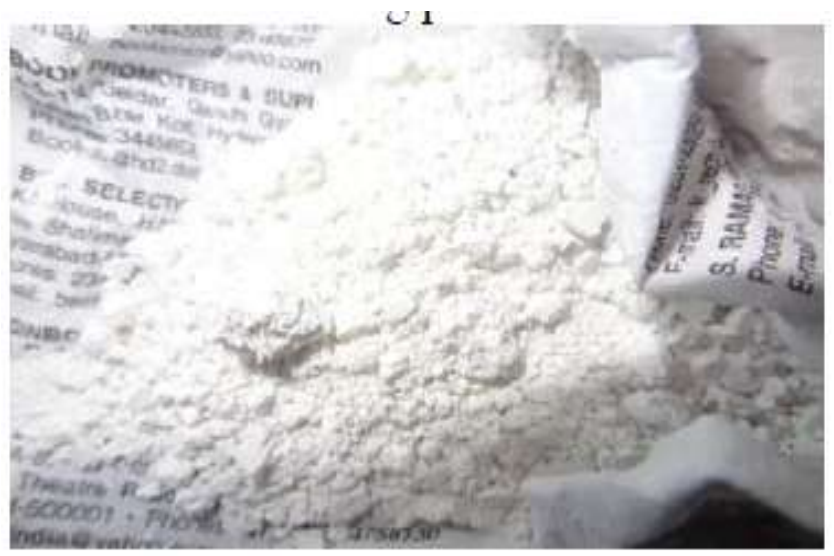

Fig - 7: Showing $\mathrm{CaCo} 3$ crystals which is used as foaming agent

As the uniformity and depth of foam was not achieved in the previous method, we tried to synthesize the foam using a foaming agent. The foaming agent used in this procedure is Calcium Carbonate.

\section{Raw Materials:}

1. Aluminum ingot $(1 \mathrm{~kg})$

2. CaCo3 Crystals ( 200 gms)

3. $\mathrm{NaCl}$ Crystals (300 gms)

\section{Procedure:}

1. Aluminum ingot is placed into the crucible for the melting process.

2. When the Aluminum starts to melt, the foaming agent is added to the crucible.

3. Once we add $\mathrm{CaCo} 3$ into the crucible, the melt and the foaming agent is continuously stirred so that $\mathrm{CaCo} 3$ crystal and the melt can agglomerate.

4. The stirring of the melt must be continuous, if not then the $\mathrm{CaCo} 3$ crystals will float on the metal melt due to the density difference (Density of $\mathrm{CaCo} 3$ crystals $=0.97$ $\mathrm{Kg} \backslash \mathrm{m} 3)$.

5. The temperature of the melt must be maintained bln 6300$7500 \mathrm{C}$, because the aluminium will react with the foaming agent at $7100 \mathrm{C}$.

6. On the other hand mould is cleaned and $\mathrm{NaCl}$ crystals are placed at the bottom of the cleaned mould.

7. Once the metal and the foaming agent agglomerate, this mixture is added to the mould which contains $\mathrm{NaCl}$ crystals.

8. Then the casting is allowed to cool for some time.

9. After the solidification, the casting is removed from the mould and is taken for the leaching process.

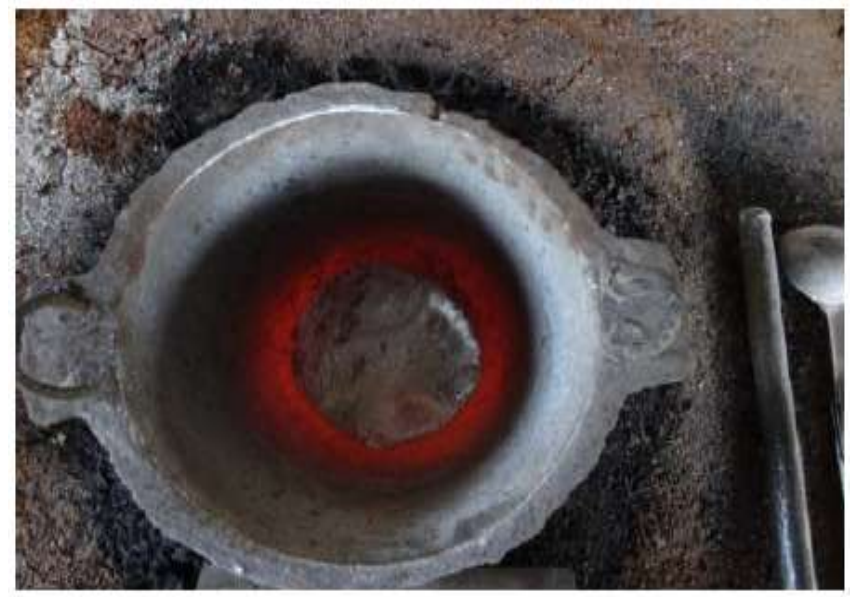

Fig -8: Mixture of molten metal and the foaming agent

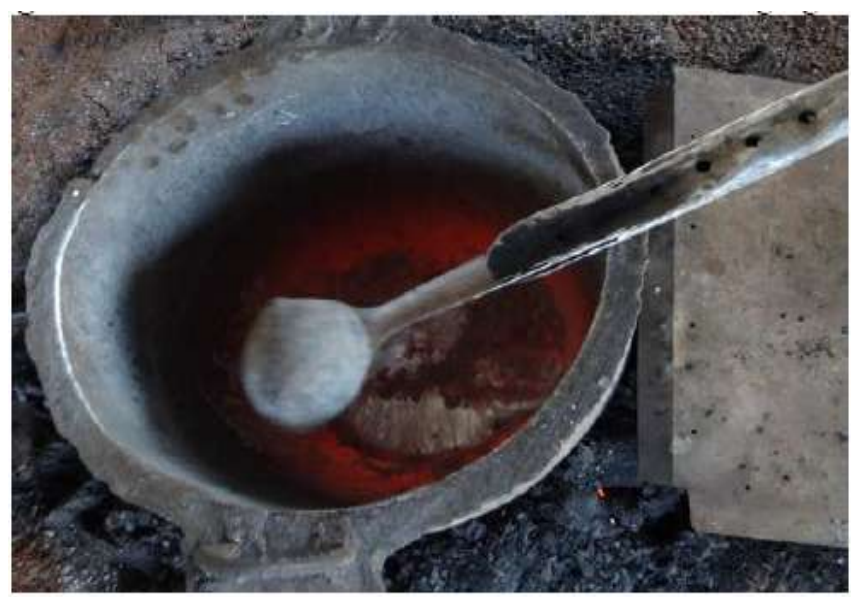

Fig - 9: Stirring the mixture of metal and foaming agent.

From the observation it was seen that the depth of the foam obtained was good. But the uniformity was not achieved.

\subsection{Fusion Method}

As the uniformity was not obtained in foaming method, we tried to synthesize the foam by fusion method. 


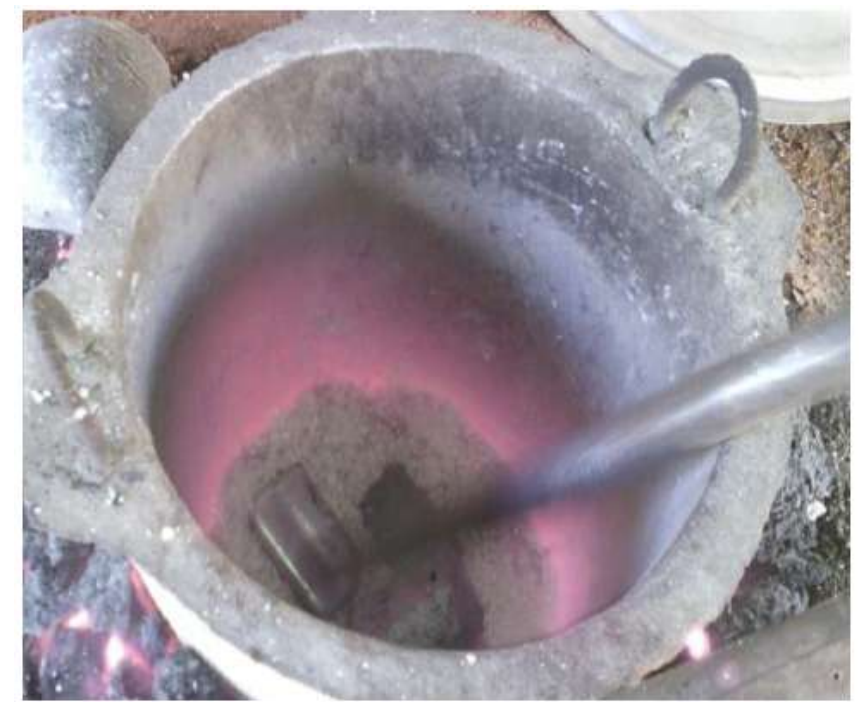

Fig - 10: Figure showing $\mathrm{NaCl}$ crystals and the aluminium ingot in the crucible

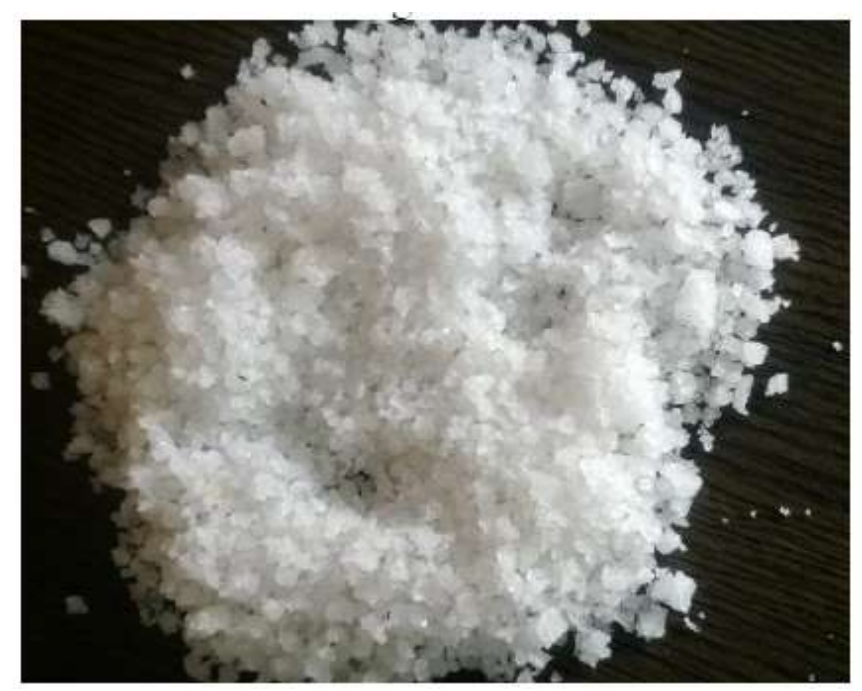

Fig - 11: $\mathrm{NaCl}$ Crystals used in the Fusion process

\section{Raw Materials:}

1. Aluminium ingot $(1 \mathrm{~kg})$

2. $\mathrm{NaCl}$ Crystals $(1 \mathrm{~kg})$

\section{Procedure:}

1. Aluminium ingot is placed in the crucible for the melting process.

2. Salt crystals are also added into the crucible after 20 minutes.

3. This mixture is heated to a temperature of $6300 \mathrm{C}$.

4. At this temperature, Aluminium starts to melt.

5. Once the aluminium starts to melt, we should continuously stir the salt in the crucible.

6 . The temperature of the melt must be maintained bln 60008000C.

7. Once the temperature reaches $7300 \mathrm{C}$, the $\mathrm{NaCl}$ crystals starts to fuse with the aluminium.

8. Stirring must be done continuously or else there is a chance of formation of lumps in the melt, i.e. the $\mathrm{NaCl}$ crystals will not fuse with the metal, instead they form clusters inside the metal which affects the property of the foam obtained.

9. In this method salt is not placed at the bottom of the mould, as we add them directly into the crucible.

10. Once the metal and foam fuses, this mixture is poured into the cleaned mould and is allowed to cool for some time. 11. After the solidification, the casting is removed from the mould for the leaching process.

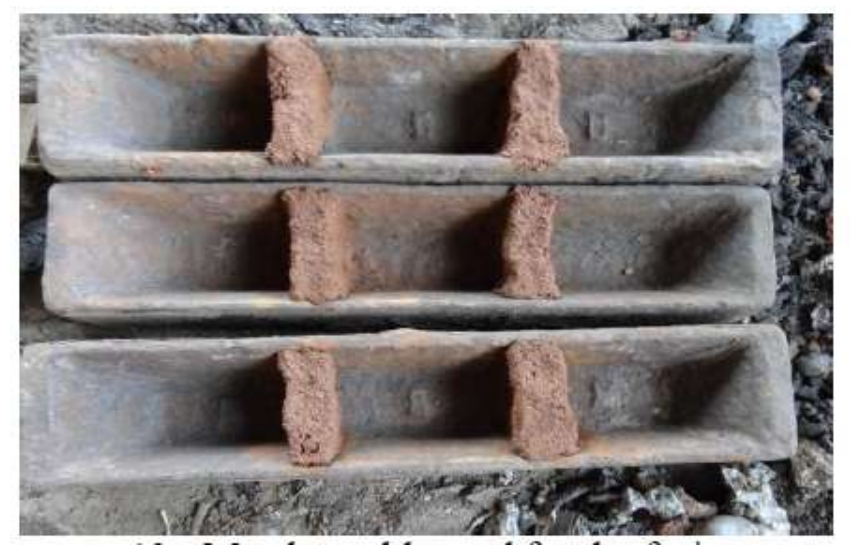

Fig - 12: Metal moulds used for the fusion process

From the observation it was seen that the depth of the foam and also the uniformity of the foam was better than the earlier two processes.

\subsection{Leaching Process}

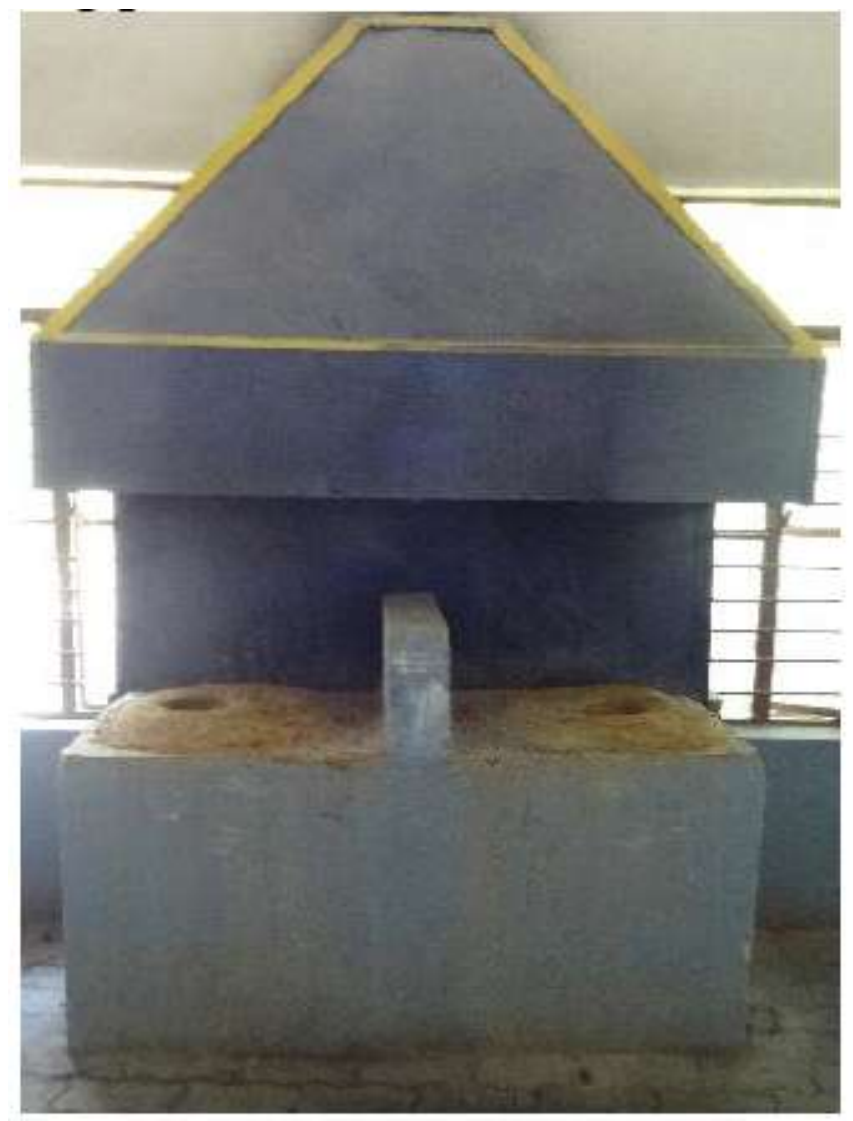

Fig - 13: Open furnace used for leaching process 
Leaching is the process of extraction of minerals from a solid by dissolving them in a liquid medium. Process of leaching is effective if some agents are dissolved into the liquid medium. These agents are known as Leaching agents. The leaching agent used in the process is Citric acid crystals. And the process is carried out on an open furnace.

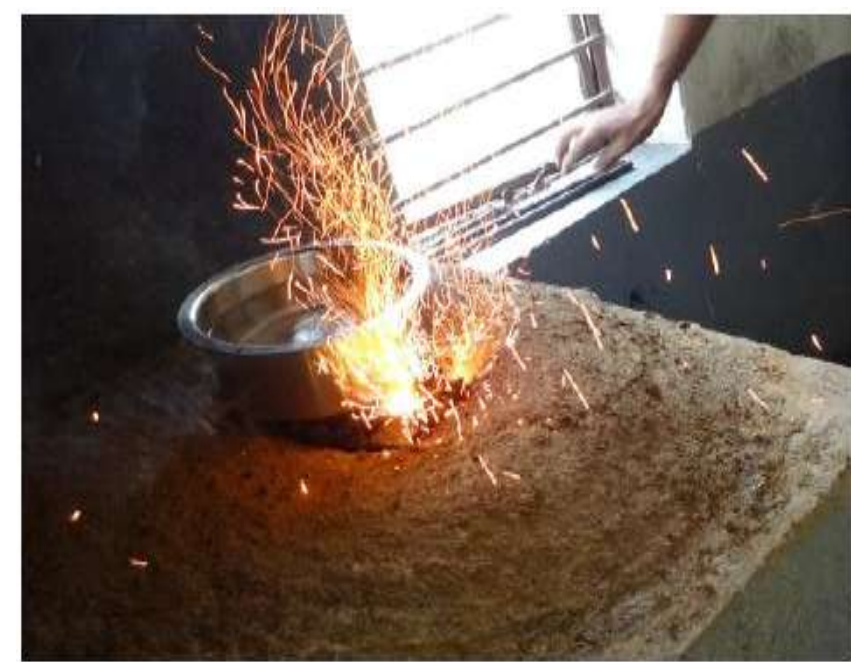

Fig - 14: Mixture of water and citric acid is heated in the steel container

The Leaching process is done as follows,

1. Water is added into a steel container and is heated.

2. When the water starts to boil, the citric acid crystals are added into the container.

3. When the crystals are dissolved, the sample is added into the container.

4. The sample should be left in the boiling citric acid solution up to 15-20 minutes minimum.

5. After 25 minutes, the sample is removed from the container.

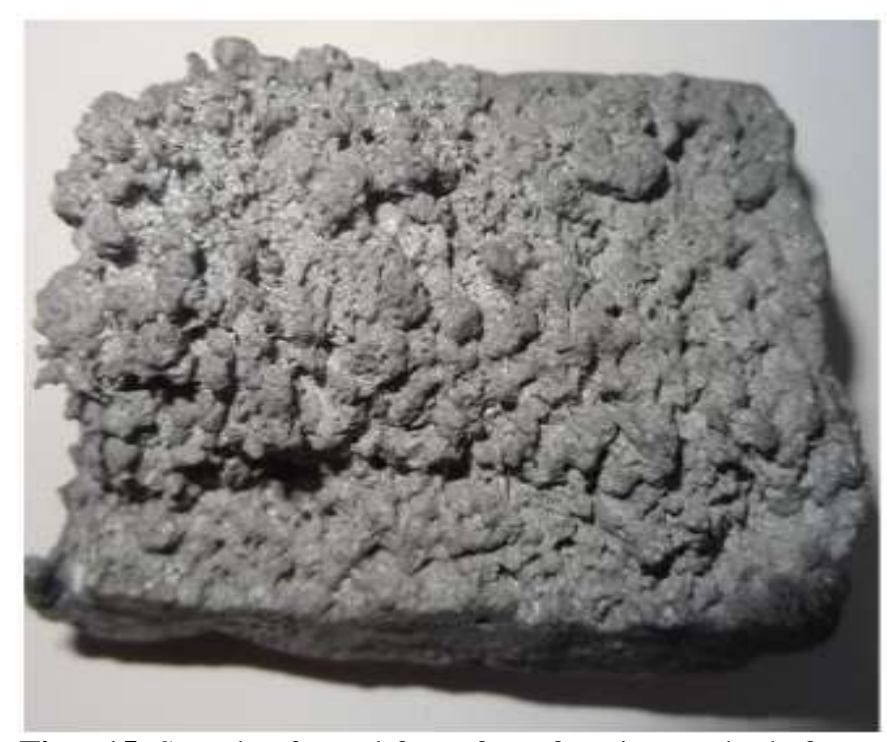

Fig - 15: Sample of metal foam from foaming method after Leaching process

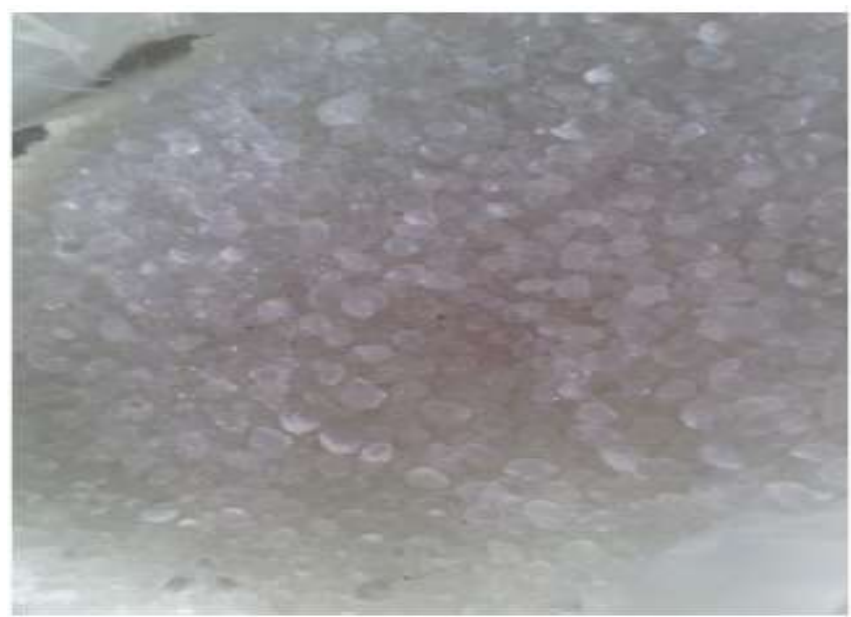

Fig - 16: Citric acid Crystals used in the Leaching Process

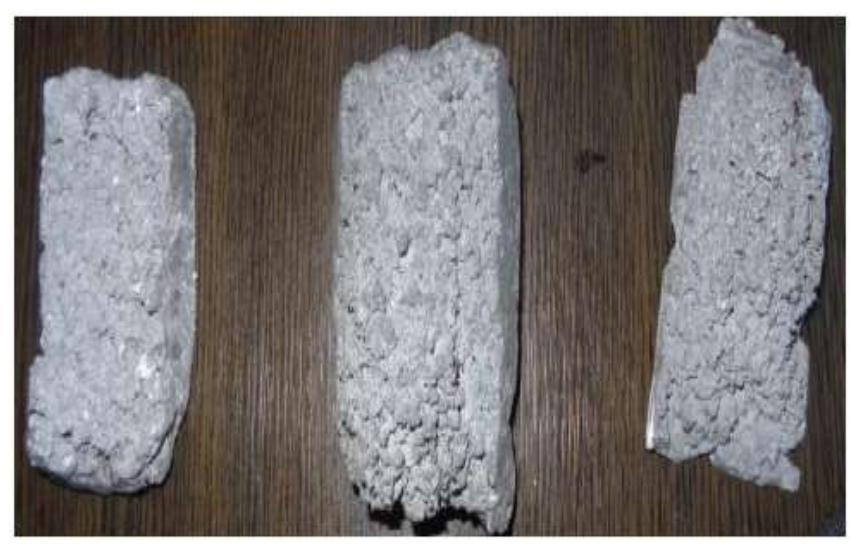

Fig - 17: Figure shows the sample of the metal foam from each process

After the leaching process, the top portion of the sample is removed by the hacksaw, because during the synthesis, the top portion of the sample was open to the atmosphere. Due to which the foam will not be obtained at the top portion.

Table - 1: Shows the details of Raw-material, Quantity and Temperature maintained in different processes

\begin{tabular}{|c|c|c|c|}
\hline Process & $\begin{array}{l}\text { Raw } \\
\text { materials }\end{array}$ & Quantity & Temperature \\
\hline $\begin{array}{l}\text { Direct } \\
\text { pouring } \\
\text { Method }\end{array}$ & $\begin{array}{c}\text { Aluminium } \\
\text { ingot } \\
\text { NaCl } \\
\text { crystals }\end{array}$ & $\begin{array}{l}\text { Ikg of } \\
\text { Aluminium } \\
\text { and } 500 \mathrm{gms} \\
\text { of } \mathrm{NaCl} \\
\text { crystals }\end{array}$ & $660^{\circ}-690^{\circ} \mathrm{C}$ \\
\hline $\begin{array}{l}\text { Foaming } \\
\text { Method }\end{array}$ & $\begin{array}{l}\text { Aluminium } \\
\text { ingot } \\
\mathrm{NaCl} \\
\text { Crystals } \\
\mathrm{CaCO}_{3} \\
\text { crystals }\end{array}$ & $\begin{array}{l}\text { 1kgof } \\
\text { Aluminium, } \\
200 \mathrm{gms} \text { of } \\
\mathrm{CaCO}_{3} \\
\text { crystals and } \\
500 \text { gins of } \\
\mathrm{NaCl} \text { crystals }\end{array}$ & $630^{\circ}-750^{\circ} \mathrm{C}$ \\
\hline $\begin{array}{l}\text { Fusion } \\
\text { Method }\end{array}$ & $\begin{array}{l}\text { Aluminium } \\
\text { ingot } \\
\mathrm{NaCl} \\
\text { Crystals }\end{array}$ & $\begin{array}{l}1 \quad \mathrm{~kg} \text { of } \\
\text { Aluminimu } \\
\text { and } \quad 1 \mathrm{~kg} \\
\text { of } \mathrm{NaCl} \\
\text { crystals } \\
\end{array}$ & $600^{\circ}-800^{\circ} \mathrm{C}$ \\
\hline
\end{tabular}




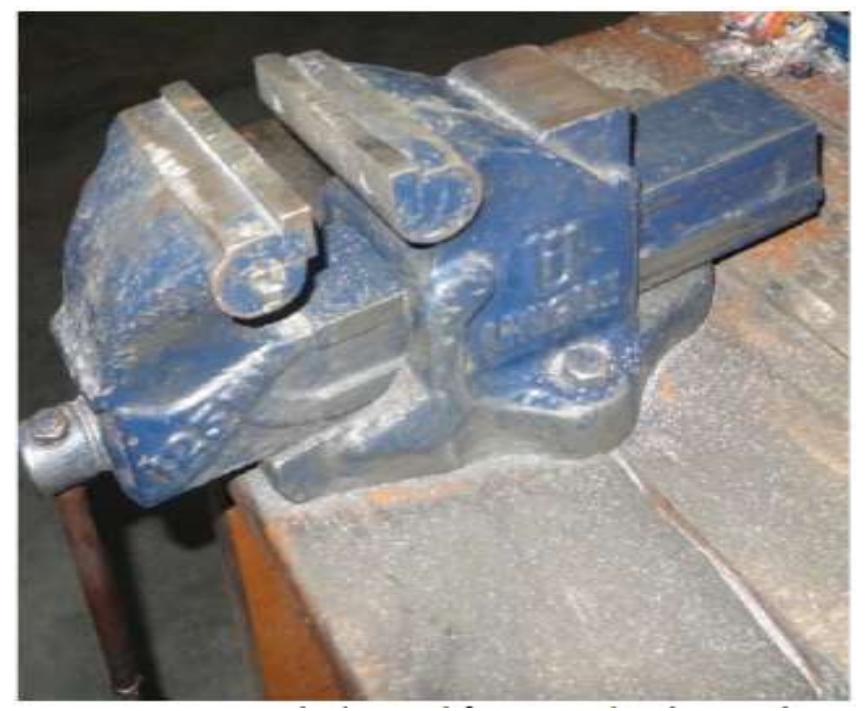

Fig - 18: Bench vice used for supporting the sample

\section{EVALUATION OF DENSITY}

The reason for considering the density property is that, the main objective of every material research person is that to reduce the density of the material. As the Foams obtained are in irregular shape, the density calculation in normal method is not possible. However it can be calculated using Archimedes principle. Archimedes' principle indicates that the upward buoyant force that is exerted on a body immersed in a fluid, whether fully or partially submerged, is equal to the weight of the fluid that the body displaces.

\subsection{To Calculate The Mass}

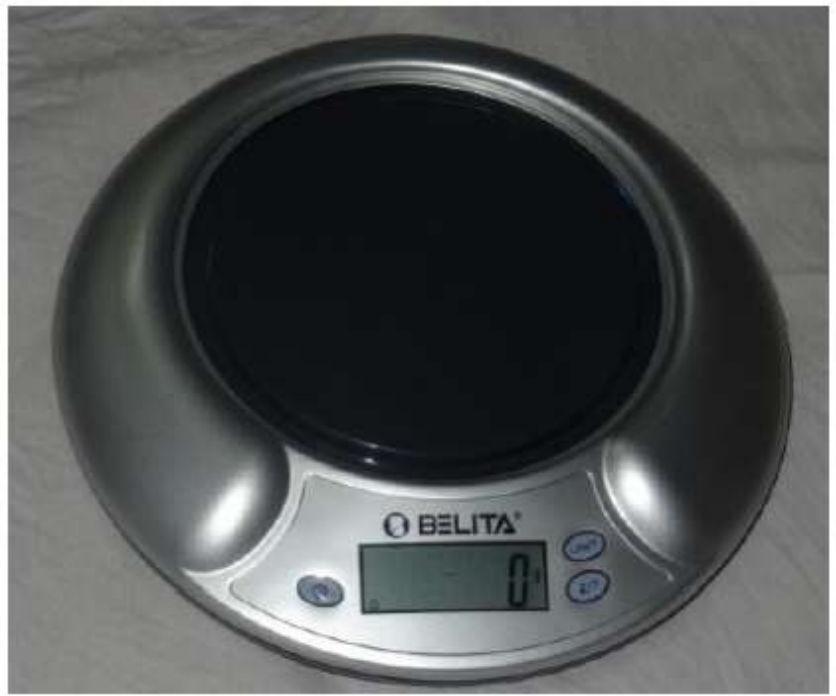

Fig - 19: Weighing scale used for the measurement of mass of the specimen

The specimens from each process were weighed individually by a weighing scale. It has to be seen that the weighing scale is calibrated correctly to eliminate the wrong reading. The weighed mass is taken in terms of grams. The weighing machine used for calculating is shown in figure 19

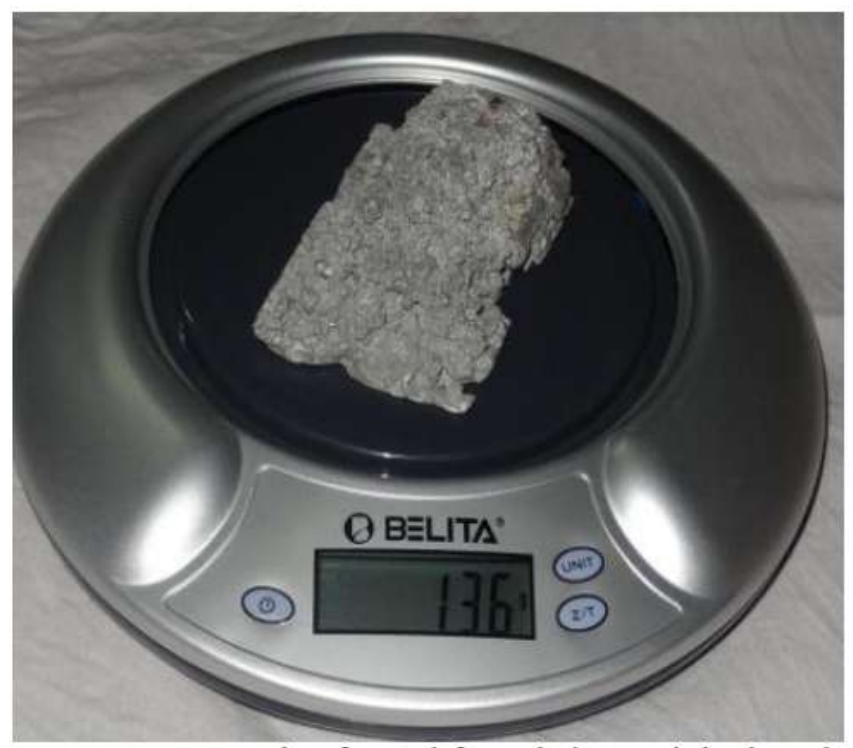

Fig - 20: Sample of metal foam being weighed on the weighing scale

\subsection{To Calculate the Volume:}

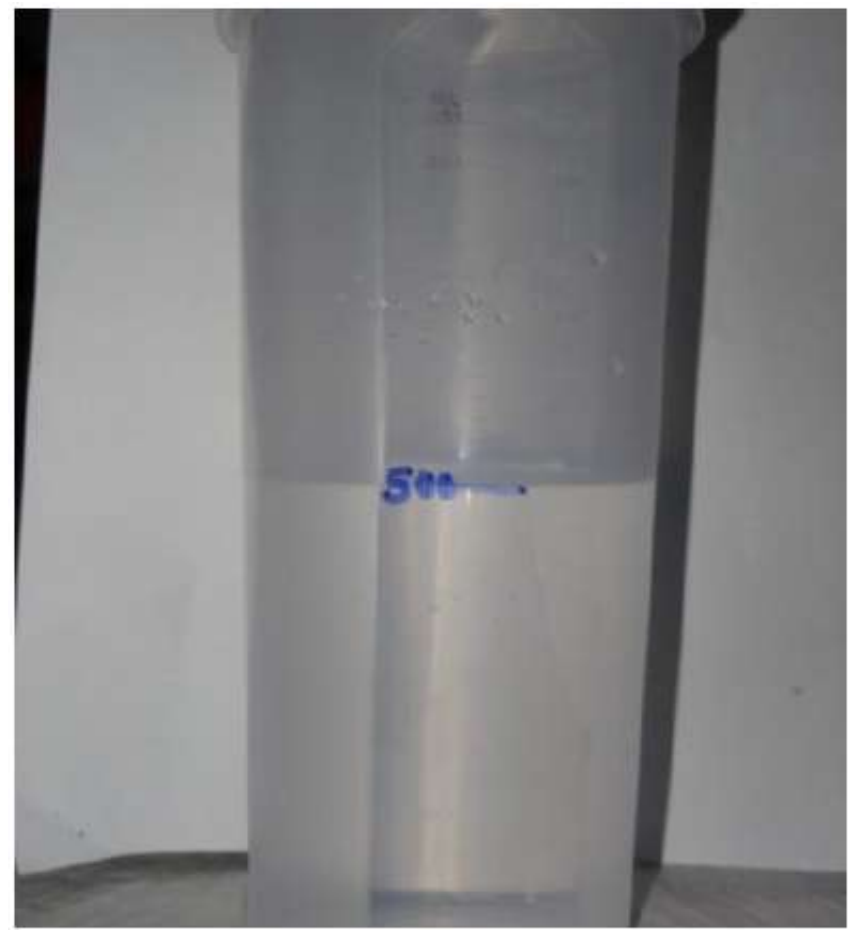

Fig-21: Figure showing the initial level of water in the measuring jar 


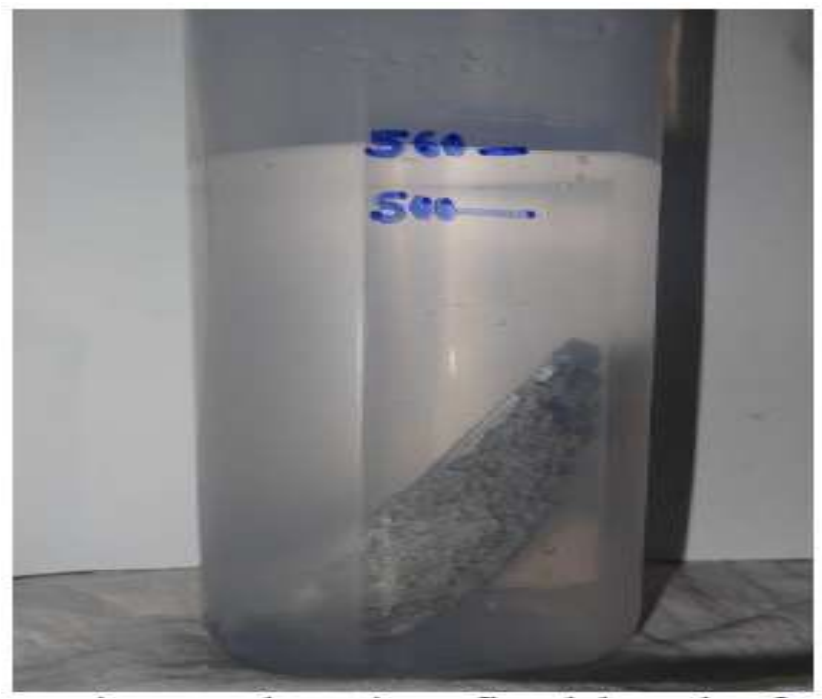

Fig - 22: Figure showing final level of water in the measuring jar

The volume is calculated as follows,

1. Water was filled in a Measuring jar for specified amount ( $\mathrm{Eg}: 500 \mathrm{ml})$. This level is treated as initial level in the measuring jar.

2. Then immerse the foam obtained into the water contained measuring jar slowly and hence new level of water is recorded.

3. This new level is treated as the final water level in the measuring jar.

4. Difference bln the initial and final level of water in the measuring jar is calculated, which gives the actual volume of the foam specimen. ( $\mathrm{V}$ in $\mathrm{cc}$ ).

5. Once the values of volume and mass are calculated, they are substituted in the formula,

$$
\operatorname{Density}(\rho)=\operatorname{Mass}(\mathrm{m}) \operatorname{Volume}(\mathrm{v})(\mathrm{g} / \mathrm{cc})
$$

In order to compare the density of foam to the actual metal, density of a whole aluminium block is calculated with the same method. The aluminium block used is as shown in the fig.

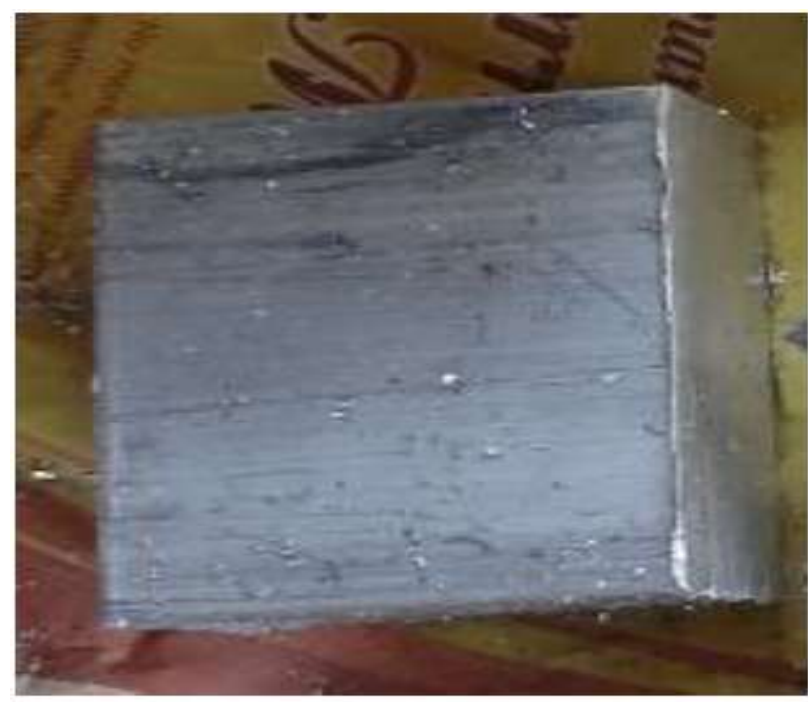

Fig - 23: Aluminium block
Table 2: shows the efficiency of different methods, i.e. how the density of foam is reduced.

\begin{tabular}{|c|c|c|c|c|c|}
\hline \multirow{2}{*}{$\begin{array}{l}\text { SI } \\
\mathrm{N} \\
0\end{array}$} & \multirow{2}{*}{$\begin{array}{l}\text { Metho } \\
\text { d } \\
\text { follow } \\
\text { ed for } \\
\text { synthe } \\
\text { sis }\end{array}$} & \multirow[t]{2}{*}{$\begin{array}{l}\text { Volume( } \\
\text { cc) }\end{array}$} & \multirow{2}{*}{$\begin{array}{l}\text { Mass } \\
\text { of that } \\
\text { Specim } \\
\text { en } \\
\text { (g) }\end{array}$} & \multicolumn{2}{|c|}{$\begin{array}{l}\text { Density }=(m) /(v) g / \\
\text { cc }\end{array}$} \\
\hline & & & & $\begin{array}{l}\text { Densit } \\
y \text { of } \\
\text { Specim } \\
\text { en }\end{array}$ & $\begin{array}{l}\text { Density } \\
\text { of } \\
\text { Allumini } \\
\text { um }\end{array}$ \\
\hline 1 & $\begin{array}{l}\text { Fusion } \\
\text { metho } \\
\text { d }\end{array}$ & 60 & 136 & 2.26 & 2.84 \\
\hline 2 & $\begin{array}{l}\text { Direct } \\
\text { pourin } \\
\text { g } \\
\text { metho } \\
\text { d }\end{array}$ & 65 & 168 & 2.58 & 2.84 \\
\hline 3 & $\begin{array}{l}\text { With } \\
\text { Foami } \\
\text { ng } \\
\text { Agent }\end{array}$ & 45 & 116 & 2.32 & 2.84 \\
\hline
\end{tabular}

By observing the table, it can be seen that method like fusion method using $\mathrm{NaCl}$ helps in reducing the density up to an extent. By our experiment we got an irregular shape of aluminium foam metal, but it is very difficult to calculate the density of an irregular foam, therefore we opted for the Archemides principle to calculate the density of the obtained the metal foam.

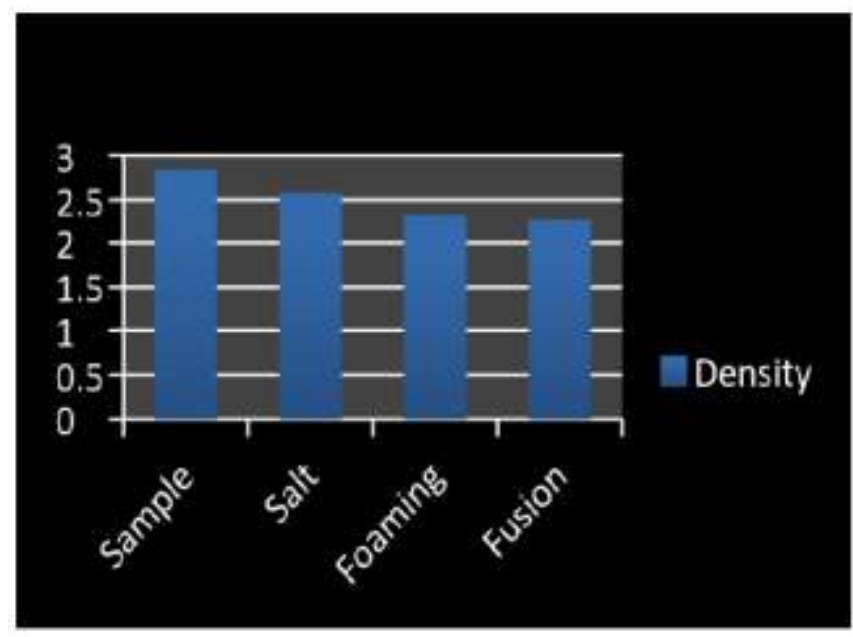

Graph .1 shows the density for different processes

\section{EVALUATION OF \% OF POROSITY}

Porosity also plays an important role as the density in deciding the foam quality. Density and Porosity are inversly proportional to each other i.e. as the density of the foam decreases, the porosity increases. But the increase in porosity not helps the quality of foam. Instead for a foam uniform porosity is the important parameter. In the cast parts actually porosity is a problem, but in the metal foam synthesis main objective is to develop uniform porosity. Simple concept of the evaluating the percentage of porosity is given below,

$\%$ of Porosity=Density of Aluminium - Density of Foamed SpecimenDensity of the Aluminium $\times 100$ 
The procedure to calculate the porosity is as given below, 1. From the Density Calculation we will be having values of density of the each Specimen.

2. Using the above values and using the Density of Alluminum we can calculate Porosity.

3. Subtract the values of Density of Foamed Specimen From Density of Alluminium $(2.84 \mathrm{~g} / \mathrm{cc})$.

4. And Divide the above Subtracted Value from Density of Alluminium $(2.84 \mathrm{~g} / \mathrm{cc})$.

5. Multiply the above Value from 100 in order to get the Percentage of Porosity

Table 3, shows the density decreases, the porosity in the foam increase

\begin{tabular}{|c|c|c|c|c|}
\hline \multirow[t]{2}{*}{$\begin{array}{l}\text { S1 } \\
\text { No }\end{array}$} & \multirow{2}{*}{$\begin{array}{l}\text { Method } \\
\text { followed } \\
\text { for } \\
\text { synthesis }\end{array}$} & \multicolumn{2}{|c|}{$\begin{array}{c}\text { Density }= \\
\text { MassVolume }(\mathrm{g} / \mathrm{cc})\end{array}$} & \multirow{2}{*}{$\begin{array}{c}\% \text { of } \\
\text { porosity }=\rho a- \\
\rho f \rho a\end{array}$} \\
\hline & & $\begin{array}{l}\text { Density } \\
\text { of } \\
\text { Specimen }\end{array}$ & $\begin{array}{l}\text { Density of } \\
\text { Aluminimm }\end{array}$ & \\
\hline 1. & $\begin{array}{l}\text { Fusion } \\
\text { method }\end{array}$ & 2.26 & 2.84 & 20.42 \\
\hline 2. & $\begin{array}{l}\text { Direct } \\
\text { pouring } \\
\text { method }\end{array}$ & 2.58 & 2.84 & 9.15 \\
\hline 3. & $\begin{array}{c}\text { With } \\
\text { Foaming } \\
\text { Agent }\end{array}$ & 2.32 & 2.84 & 18.30 \\
\hline
\end{tabular}

Graph 2 shows the \% of porosity for different processes,

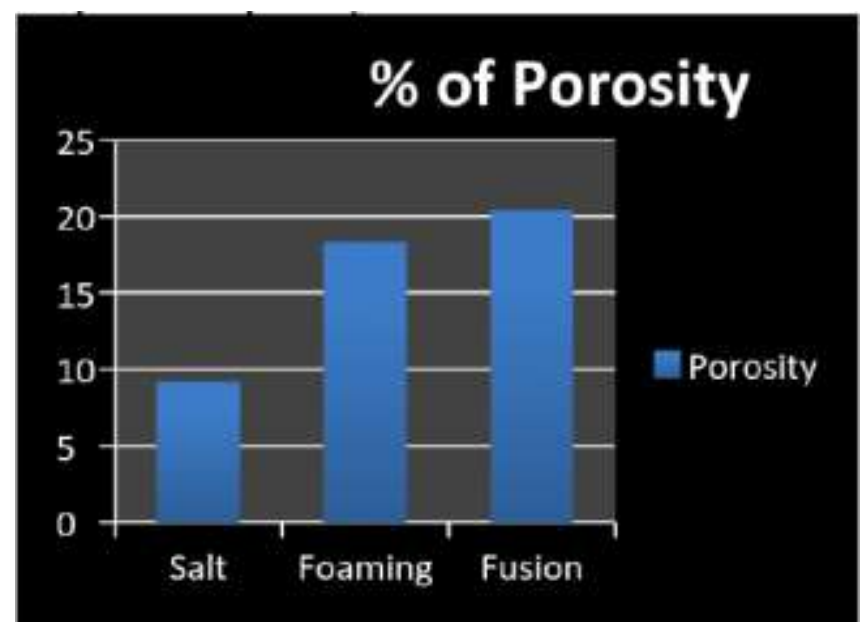

Graph 2: \% of porosity v/s Process

\section{CONCLUSION}

The method for producing the aluminium foam was developed by pouring the molten aluminium into the mould containing $\mathrm{NaCl}$ crystals i.e. direct Pouring Method. In this Method, foam was obtained, but the structure was not satisfactory. Because depth and uniformity of the foam was not obtained. In Foaming method, foaming agent such as $\mathrm{CaCO} 3$ was added to the molten aluminium which was poured into the mould having $\mathrm{NaCl}$ crystals. Though this method helped in the formation of metal foam, the quality of the foam produced was not up to the mark. Because the depth of the foam was good, but it failed in maintaining the uniformity of the foam obtained. In Fusion method, $\mathrm{NaCl}$ crystals were added into the crucible having Aluminium ingot. In this method, the depth and uniformity of the foam was better compared to the previous two methods. But the main problem is that fluidity of Aluminium is low and while pouring into the mould it rapidly solidifies, which results in the coagulation of salt particles inside the mould and obtained foam structure is not satisfactory. In terms of density of the foam, structure obtained by fusion concept was good, but density is not only parameter which decided the quality of the foam or any material. Some other parameters like porosity, compactness etc also plays vital role. But the methods for characterising the above properties are still in incipient stage. Therefore much more efforts are needed in development of Aluminium foams and its characterisation methods. In terms of Porosity of the foam, structure obtained by fusion method had more porosity. But increase in porosity not helps; instead for the foam uniform porosity is the important parameter. In the metal foam synthesis main objective should be to develop uniform porosity.

\section{REFERENCES}

[1]. J. Banhart, J. Baumeister, M. Weber, "Powder Metallurgical Technology for the Production of Metallic Foams", Proceedings of the European Conference on Advanced PM Materials (PM'95)

Birmingham (UK), 23.-25.10.1995 (European Powder Metallurgy Association, Shrewsbury) pp. 201-208.

[2]. B.U. Vinay and K.V. Sreenivas Rao, "Development of Aluminum Foams by Different Methods and Evaluation of its Density by Archimedes Principle", Bonfring International Journal of Industrial Engineering and Management Science, Vol. 2, No. 4, December 2012.

[3]. Lucai WANG, Haijuan LI, Fang WANG, Jianfu REN, "Preparation of open-cell metal foams by investment Cast", (Taiyuan University of Science and Technology, Taiyuan 030024, Shanxi, P. R. China), TG249.5,TG133, 16726421(2005)01-0056-04.

[4]. Jan Schroers,Chris Veazey, Marios D. Demetriou, and William L. Johnson, "Synthesis method for amorphous metallic foam", journal of applied physics, volume 96, number 12, 2004 American Institute of Physics. [DOI: 10.1063/1.1818355].

[5]. Varužan Kevorkijan, "Low cost aluminium foams made by caco3 particulates", Association of Metallurgical Engineers of Serbia, UDC: 549.74:621.762. 